\title{
Training of workers of the public in France ${ }^{1}$
}

UDC 327.57

DOI https://doi.org/

10.24195/2414-9616-2019-2-85-89

Dadashova Ramila Bahlul

Ph.D. in Historical sciences, Docent, Deputy Director for Science

Institute of Caucasus Studies of Azerbaijan

National Academy of Sciences

Huseyn Javid Ave., 115, Azerbaijan, Baku

Omarov Vahid Allahverdi oglu

Ph.D. in Philosophy, Docent,

Head of Georgian Studies Department

Institute of Caucasus Studies of Azerbaijan

National Academy of Sciences

Huseyn Javid Ave., 115, Azerbaijan, Baku
IPAG and the National CPAG conference from 28 institutes (Conférence Nationale des Directeurs) are coordinated with the universities and political research institutes and work in all areas, including abroad. The contract signed between the employee and appropriate authority reflects functions of the employee, duration of the qualification period, quality which need to be got, and preparation which needs to be carried out. The qualification period is a part of total or partial working hours, and training is provided after the consent of the officer. The highest public administration (École Nationale d'Administration (ENA) founded in 1945 trains highly skilled public servants and this school in France differs from other countries in terms of scales of activity and educational programs of high level. From this point of view, it is expedient to study the training program of ENA and to apply it to schools at which frames of public administration in Azerbaijan are created. The academy of public administration under the President of the Azerbaijan Republic is the main scientific and methodical and education center concerning preparation, retraining and professional development of public servants. Preparation of the managerial personnel is successfully carried out in France. Cooperation between Academy and foreign countries, including France, expediently. The academy of public administration under the President of the Azerbaijan Republic can cooperate with School of public administration in Strasbourg, France (École Nationale d'Administration (ENA)) and implementation of five ENA programs in Academy can be of great importance.

Key words: education, institute of management, public servants, training, international program, employee, public administration, Azerbaijan, France.
Studying of experience of public servants in foreign countries is important from the point of view of what experience of the application of the concept of reforms in Azerbaijan. Studying of experience of foreign countries in training allows defining ways of improvement of training of public service in the country and its efficiency. It is undoubted that during the reforms undertaken in this area it is necessary to study various elements of public service of the developed countries according to national peculiarities. For this purpose on the basis of educational programs of School of public administration (Ecole Nationale d'Administration - ENA) studied educational programs of the most influential institution in the field of training of public servants in France, one of the developed European states, and in Azerbaijan, very important scientific results are achieved.

Preparation of cards of management in France.

The French Institute of management training (Instituts de Préparation à l'Administration Générale - IPAG) and the centers of management training (Centres de Préparation à l'Administration Générale - CPAG) work in the field of foreign competitions, practice and training of public servants. Results show the efficiency, relevance, and durability of these medicines [1]. 23 universities, including National Institute of territorial researches in Saint Etienne, are a part of IPAG (Institut National des Études Territoriales - INET) and the Public school of social security (École Nationale Supérieure de Sécurité Sociale - EN3S) which serves for training of leaders

${ }^{1}$ The work was supported by the Science Development Foundation under the President of the Republic of Azerbaijan - Grant № EiF MQM/Elm-Tehsil-1-2016-1(26)-71/06/5. in the field of social protection, the Regional Institutes of health care (Instituts Régionaux d'Administration IRA) located in the Bastille, Lille, Lyon, Metz, Nantes on Rein, College of sanitary education (École des Hautes Études en Santé Publique - EHESP), the Strasbourg school of public administration (École Nationale d'Administration - ENA), CPAG which completed the work of IPAG in the state administrative frames, includes five political educational institutions operating in Aix-en-Provence, Bordeaux, Grenoble, Lyon and Toulouse.

IPAG and the National CPAG conference from 28 institutes (Conférence Nationale des Directeurs) are coordinated with the universities and political research institutes and work in all areas, including abroad [1]. IPAG and CPAG have the right to appropriate degrees of bachelors and masters, and some of them have international cooperation with other countries. With General management of IPAG and CPAG (Direction Générale de la Fonction Publique) and also with schools of public service (Réseau des Écoles du Service Public), especially with regional institutes (Instituts Régionaux d'Administration) and cooperation is carried out successfully.

How education is provided in public service? Public authorities conduct hierarchical surveys every year. This interview is intended for formation of positions of shots, allowing officials to estimate the skills, to estimate the previous experience (Validation des acquis de l'expérience - VAE), skills and professional knowledge [2]. Anyhow works professionally can benefit by assessment of VAE of the experience got in circumstances on which he works. By results of this assessment, it issues the certificate [3]. 
Before an interview, the appropriate authority prepares the report. This report is transferred to the sending body for the interviewer. Qualification is regulated by all positions of public service (public servants and contractors) [4]. The official can participate in an interview for professionalism assessment on own initiative [4]. The employee has to address the manager for participation in an interview, and he has to report about reception or refusal within two months. The offer has to be proved in case of a deviation [4]. The qualification period can be from 3 to 1 year. The contract signed between the employee and appropriate authority reflects functions of the employee, duration of the qualification period, quality which need to be got, and preparation which needs to be carried out. The qualification period is a part of total or partial working hours, and training is provided after the consent of the officer [4].

Vocational training of public servants covers the following questions:

- assessment which defines compliance of the public servant to new work;

- the decision of human resources department after the Commission of Paritaire (Commission Administrative Paritaire - CAP) [4]; during the qualification period, the official can use all vacancies (annual vacation, a sick leave, accident at work, etc.) [4].

School of public administration (École Nationale d'Administration (ENA)) and educational programs.

The highest public administration (École Nationale d'Administration (ENA) founded in 1945 trains highly skilled public servants and this school in France differs from other countries in terms of scales of activity and educational programs of high level. From this point of view, it is expedient to study the training program of ENA and to apply it to schools at which frames of public administration in Azerbaijan are created.

The school offers highly skilled courses both for young public servants and for students. One of the basic principles of international cooperation is the encouragement of exchange of the ideas and experience which change between theoretical and practical courses. ENA offers five types of international applications.

1) Short-term international program (Programmes internationaux courts - PiC (ex Cisap)). These international programs represent intensive classes in development, lasting from one week up to four weeks on a concrete subject [6]. Courses are taught in French and carried out in Paris. Some courses are offered every year in the English and Spanish languages. These programs encourage the exchange of national experience. Conferences, seminars, round tables are held. The sphere of coverage of training is focused on Europe and the international community by means of comparative approach [5]. The international program is focused, first of all, on the high-ranking officials of foreign missions, heads of the state enterprises or representatives of the non-governmental organizations wishing to improve the skills in the concrete area. These programs are open for heads of France. Program terms of use following:

- the public servant, being the public company (with the permission of ENA, the international programs can be open for other candidates);

- master or four-year higher education;

- to have experience not less than three years;

- public government or employer;

- knowledge of French language [5].

Students are accepted as inside, and beyond its limits. The registration fee for the non-French pensioners following:

- 1400 euros a week;

- two weeks for 2300 euros;

- four weeks for 3700 euros.

Costs of stay fall on the student. The French state scholarship program (which includes registration fees and expenses on accommodation) can be required from the French Embassy. Student's grants can be also paid by the national or international organization, the public organization which proposes the candidate. This grant has to be carried out by the competent authority in France.

Short international access to online applications is provided online, but elections pass through the Embassy of France in each country. Therefore applicants have to fill an application form. The statement for the applicants who came to France should be sent directly to ENA, to the Director of the international relations. The principal is appointed by Council of ministers. The ENA informs the candidates selected by election commission through the Embassy of France. Applicants who observe requirements and pay expenses on journey, accommodation, insurance and registration, are registered during a certain period of time [5].

2) Long-term international program (Cycle international long - CiL). The program will last from 14 to 16 months. One of three programs offered ENA can be continued in one of the master programs. Master programs: public service, European public affairs, and public institutions [8].

CIL allows to deepen the European data and to get acquainted with the leadership of France [7]. Foreign citizens with French citizenship cannot file documents there. The long-term international program (14 months 2 months) is intended for young foreign public servants or public servants and, in some exceptional cases, for those who live in France. This program, first of all, allows them to make use of 4-month experience, mainly with officials of ENA (Formation İnitiale-Fi), especially on the international or territorial issues [7].

The curriculum looks as follows: Within the first month of training in Strasbourg in September modern France, its principles, problems, and work of the French government is given. 4 months (Octo- 
ber - January) are spent for development of specialty of the student (the central or non-central office, the state operator, the international organization). Together with 4-month holiday students study ninemonths (February - October) training. An additional course is conducted for those who want to write and defend the master dissertation within 2 months (November and December) [7]. The training will include the international diploma under the name "Cycle international long", parallel public service (Master 2 professionnel en Administration publique générale), the European public affairs (Master 2 professionnel Affaires publiques européennes / Action publique en Europe) diplomas of graduates of the 2nd stage (Master 2 professionnel en Communication des institutions publiques).

The lectures CIL cover the next lectures:

- management of human resources, management, and public innovative initiatives,

- economy and public finances;

- state policy and territorial questions;

- European and international problems.

Entrants admission to this international program include:

- to be an official, state official or, in exceptional cases, the professional project in public service for the benefit of the country;

- to have a degree of the master or an equivalent of phase 1 ;

- to be a responsible public servant or the state official;

- excellent knowledge of French at the oral and written levels;

- well knowledge of the English language;

- to respond to the chosen tests organized by the school;

- Lack of French citizenship [7].

In spite of the registration fee, training free. The cost of a grant and experience depends on the student. These are 1400 euros a month. The grant can be also requested in the Embassy of France and also in the national or international organization, the public or private organization or the government providing the candidate. The registration fees in the master program are as follows: ENA is obliged to pay 500 euros for students who want to visit one of three master programs. Besides, the corresponding university fee (about $260 €$ ) is paid [7].

3) Program of the international period of development (Cycle international de perfectionnement CiP). This program is taught within 8 months. It is authorized to experience high-ranking officials to get acquainted with all aspects of public administration in France and Europe. At the initial stage, preference is given to comparative approaches by an association of experience and knowledge, and at a threemonth stage public servants are trained according to the program of professional development (Cycle supérieur de perfectionnement des administrateurs CSPA) and a cycle of integration of employees (Cycle d'intégration des officiers - $\mathrm{ClO}$ ). Foreign citizens with French citizenship cannot apply for the international specified program [9].

The program is divided into the next periods:

- within 11 weeks students will study bases of geopolitical problems in modern France and Europe, their situation in the world;

- 6 weeks experience of management. That is students do practical training in any public institution of France; places of training are various (the central and regional offices, prefectures, local authorities, public institutions, etc.);

- 13 weeks are taught in "A cycle of completion of administrative correction" (Cycle supérieur de perfectionnement des administrateurs - CSPA) and "A watch cycle for officials" (Cycle d'intégration des officiers - $\mathrm{ClO}$ ); this period was aimed at the development of knowledge, the analysis, predictability;

- by results of a course the international diploma of the international development in public administration (Cycle international de perfectionnement) is issued; one of the following master specialties can be provided the 2 nd stage of the master on comparative management and public administration (Master 2 professionnel Administration comparée et gestion publique - ACGP); the 2nd stage of the master in the field of public administration and international relations [9].

Conditions for revenues to a course following:

- public servant, public official;

- to have the diploma of public service of the 1st degree or the equivalent diploma;

- excellent knowledge of French language at the oral and written levels;

- knowledge of English language;

- the answer to the selective tests organized by the school (ENA) [9].

Each student has to pay 4000 euros for training. Pensions and training are 1400 euros a month paid by the pupil. The French Embassy can also demand a grant from the national or international organization, the public or private organization, or from the government providing the candidate. Additional 260 euros have to be paid to look at the master's course. Grants from the French government are free from university contributions [9].

4) The international program of institutes of regional government (Cycle international des IRACilRA). He prepared for public service in five cities of France - the Bastille, Lille, Lyon, Mets, and Nantes within 8 months (September-April). IRA carries out five main objectives: initial training of the state heads. Continuous training of the French citizens or foreign officials, holding competitions on access to IRA, an integration educational class, the international cooperation in the sphere of public administration. The international program of Regional Institute of manage- 
ment is intended for public servants who are winners of the competition IRA. The program includes public service culture, employee rights, and duties; ethical behavior rules, values, personnel management, the role of staff in social activities, the basics of communication, operative management, etc. are taught.

The following conditions are necessary for revenues to a course:

- public servant, public official;

- to have the diploma of public service of the 1st degree or the equivalent diploma;

- to have business experience;

- excellent knowledge of French language at the oral and written levels;

- response to the joint selective ENA/IRA tests covering knowledge of the French control system and the European organizations [10].

CIRA is implemented in the following stages.

- The initial stage is 6 months (September-February). This stage includes 4 months of training and 7 years of experience in management. Knowledge and basic skills, the culture of social service, methods of public administration and the corresponding skills of management are taught for the performance of institutional administrative tasks within four months of training (September/October, then January/February).

- Experience of 7 weeks (November/December) is carried out in any public institution in France. Places of training are various (the central and regional offices, prefectures, local authorities, public institutions, etc.). The place of practice is defined by the listener and his professional career.

- Deepening of a phase (March-April). This stage is an increasing knowledge stage, the general for all cadets. The maintenance of courses is focused on one of the following professions: the centralized management, Territorial Department of the state, school and university of management.

CIRA provides the certificate confirming completion of training at the end of the training period.

Training cost in CIRA is 4000 euros. The student bears responsibility for the payment of grants and expenses on experience. Grants can be required from Service of the culture of Embassy of France (Service de Coopération et d'Action Culturelle - SCAC) and also from the national or international organization, the public or private organization or the candidate proposed by the government [10].

5) The master program "European Government and Management" (Master Européen de Gouvernance et d'Administration - MEGA). MEGA is the FrenchGerman program of continuous training of public servants. To develop modern methods of management within the European and international cooperation, to create the European network of well-prepared leaders. On the occasion of the 40th anniversary of the Élysée contract in 2003 German Chancellor and the president of the French Republic expressed desire to create the new joint program of training in the government, and in 2005 - the European master program for the government and management (MEGA) In view of the needs of managers and staff of social services, MEGA introduces the 14-day four-day educational module, the module of distance learning and nine-week experience. The degree of the master is financed in common by the partner universities and gets financial support from the French-German University [11].

The academy of public administration under the President of the Azerbaijan Republic is the main scientific and methodical and education center concerning preparation, retraining and professional development of public servants. Preparation of the managerial personnel is successfully carried out in France. Cooperation between Academy and foreign countries, including France, expediently. The academy of public administration under the President of the Azerbaijan Republic can cooperate with School of public administration in Strasbourg, France (École Nationale d'Administration (ENA)) and implementation of five ENA programs in Academy can be of great importance. High level of scientific and practical skills of the employees working in public administration is very important for the further development of our state. For this purpose, it is desirable that the staff of the central public authorities in Baku and also public authorities in regions held seminars, training, conferences, trained in the knowledge of our country and also the position of our country in the world. In the course of training it is important to train in the culture of public service, the rights and duties of personnel, rules of ethical behavior, values, human resource management, and a role of personnel in public work, to communication bases, operational management. Carrying out an experiment has to be carried out in any public authority (Presidential Administration, Milli Majlis, executive authorities, etc.), Depending on the activity of the listener. Various types of educational modules have to be defined according to personnel working conditions. Along with various training programs and courses, the Academy can organize student's exchanges, conferences, annual professional meetings, the international projects and annual competitions in topical issues of public administration.

\section{LITERATURE:}

1. Les instituts de préparation à l'administration générale IPAG et les centres de préparation à l'administration générale CPAG14/08/2018. URL: https:// www.fonction-publique.gouv.fr/score/preparations-auxconcours/instituts-ipag-et-centres-cpag [in French].

2. Entretien de formation dans la fonction publique d'État (FPE) 23.04.2018. URL: www.service-public.fr/ particuliers/vosdroits/F20094 [in French].

3. Validation des acquis de l'expérience (VAE) 01.01.2019. URL: www.service-public.fr/particuliers/vosdroits/F2401 [in French]. 
4. Période de professionnalisation dans la fonction publique d'État (FPE) 05.12.2018. URL: https://www.service-public.fr/particuliers/vosdroits/F2749 [in French].

5. Programmes internationaux courts - ex Cisap (1 à 4 semaines). URL: https://www.ena.fr/Formation-continue/Programmes-Internationaux-et-d-approfondissement/Programmes-internationaux-courts-exCisap [in French].

6. Programmes Internationaux et d'approfondissement. URL: https://www.ena.fr/Formation-continue/ Programmes-Internationaux-et-d-approfondissement [in French].

7. Cycle international long (CIL - 14 mois à 16 mois). URL: https://www.ena.fr/Formation-continue/ Programmes-Internationaux-et-d-approfondissement/cil [in French].
8. Masters du CIL. URL: https://www.ena.fr/Formation-continue/Programmes-Internationaux-et-d-approfondissement/cil/Masters-du-CIL [in French].

9. Cycle international de perfectionnement (CIP - 8 mois). URL: https://www.ena.fr/Formation-continue/Programmes-Internationaux-et-d-approfondissement/cip [in French].

10. Cycle international des IRA (CilRA-8 mois). URL: https://www.ena.fr/Formation-continue/Programmes-Internationaux-et-d-approfondissement/cilRA [in French].

11. Master Européen de Gouvernance et d'Administration (MEGA). URL: https://www.ena.fr/Formation-continue/Masters-et-Masteres/Masters-professionnels-organises-avec-des-universites-partenaires/MEGA [in French].

\section{Навчання громадських працівників у Франції}

\section{Дадашова Раміля Бахлул}

доктор фрілософфії з історичних наук, доцент,

заступник директора з наукової роботи Інституту досліджень Кавказу

Національної академії наук Азербайджану пр. Гусейна Джавіда 115,

Баку, Азербайджан

Омаров Вахід Аллахверді оглу

доктор фрілософрії з фрілософрських наук, доцент,

завідуючий відділом Грузіїзнавства Інституту досліджень Кавказу

Національної академії наук Азербайджану пр. Гусейна Джавіда 115,

Баку, Азербайджан
Національна конференція директорів IPAG і CPAG, що складається з 28 інститутів, координується з університетами та політичними дослідними інститутами й діє по всій країні, включаючи весь регіон. У договорі, укладеному між співробітником та відповідним органом, фрункції співробітника, тривалість квалісрікаційного періоду є частинами повного або часткового робочого часу, а також прописано заходи, вжиття яких необхідне для звільнення співробітника. Школа державного управління, створена у 1945 році, готує висококвалірікованих державних службовців, і ця школа у Франції відрізняється від шкіл інших країн за масштабом діяльності та різними освітніми програмами високого рівня. Отже, доцільно вивчити програму навчання ENA та застосувати ії до шкіл, в яких створені структури державного управління в Азербайджані. Академія державного управління при Президенті республіки Азербайджан є основним, науковим, методичним та освітнім чентром щодо підготовки, перенавчання та профресійного розвитку державних службовців. Підготовка організаторського персоналу успішно виконана у Франції. Співпраця між Академією та зарубіжними країнами, включаючи Францію, $є$ доцільною. Академія державного управління при Президенті республіки Азербайджан може співпрацювати зі Школою державного управління в Страсбурзі, Франція (École Nationale d'Administration (ENA)), а впровадження п'яти програм ENA в Академії може бути дуже важливим.

Ключові слова: освіта, інститут управління, державні службовці, навчання, міжнародна програма, співробітник, державне управління, Азербайджан, Франція. 